\title{
Determination of safe social networking use levels of teacher candidates
}

\author{
Aynur Geçer and Nilgün Tosun \\ Faculty of Education, Department of Computer and Instructional Technologies Education, Kocaeli University, \\ Turkey
}

Correspondence should be addressed to Dr. Aynur Geçer iD aynurgecer@hotmail.com Received 30 August 2021; Revised 8 February 2022; Accepted 10 February 2022

\begin{abstract}
Social networks are platforms that have entered our lives together with the development of web 2.0 technologies, with millions and even billions of users. In response to many positive aspects, the safe use of social networks, including some threats and risks, is an important issue for the individual, institutional and national safety. This study is to investigate the level of safe social network usage of teacher candidates and to demonstrate whether the status of using secure safe networking varies according to demographic variables. The study group consisted of teacher candidates from a state university, Faculty of Education in Turkey. The survey model was used in this study. According to the findings obtained from the analyses, half of the teachers' candidates use social network around 1-3 hours average per day. The aim of using social networks is to communicate and chat with their friends at the very beginning. The behavior of the teachers who participate in the study is the use of safe social networking behaviors at a high level.
\end{abstract}

Keywords: social networking, security, teacher candidates, safe social networking use, Safe Social Networking Scale, large survey

\section{Introduction}

Social networks are an important place among web-based software, with interactive environments where users can produce content directly, share content they produce, interpret, record, and edit shares. Due to these possibilities, the number of users is constantly increasing, both learning and teaching activities, as well as the Web platforms where student-teacher-family communication can be done without limitation of time and space, reveals the importance of social networks. In this period when the digital native generation began to use social networks intensively and continued, integration into education has become almost a necessity. This necessity is expressed by a lot of institutions or organizations such as ISTE and NETS-T operating in the field of educational technologies and use. In 2018, The Ministry of National Education [MoNE] of the Republic of Turkey announced in the "2023 Education Vision" document, where teachers should have the qualifications to use educational technologies and the transformation plans in the educational system (MoNE, 2018). Not only because of these standards, but also because of its role model characteristics, teachers are obliged to use social networks consciously and securely, as well as all learning and teaching tools. As with many web platforms, social networks also have various dangers within the site (Tosun, 2018). Therefore, teachers should be aware of the dangers in social networks, take precautions against them, know how to behave in the face of danger, as well as for their students and their parents, secure learning and communication, it is important to provide the environment. The General Competence of Teaching Profession issued by the General Directorate of Teacher Training and Development of the Ministry of National Education of the Republic of Turkey also states that the teacher prepares healthy and safe learning environments for all students in which effective learning can take place. In another proficiency statement in the same document, it is pointed out that teachers should actively use information and communication technologies in the process of learning and teaching (MoNE, 2017). 
Since it is possible for individuals from all age groups to access it free of charge and the number of users is constantly increasing (Kemp, 2022), social networks; It is used for many purposes such as communication, entertainment, sharing, obtaining information, commerce and education. Individuals use information about themselves, their family, relatives or the institution they work for when creating a social network profile. The fact that social networks have some risks as well as advantages cannot be ignored due to people using this information maliciously (Ohlhorst, 2021; Stouffer, 2021). Risks such as personal or corporate data theft, fraud, cyberbullying, social engineering and profile copying can cause financial and moral damage to individuals, as well as financial and reputational damage to institutions where people work or study. According to the data of a study; the number of records regarding crimes committed on social media platforms worldwide in 2019 is 9.6 billion (Lazic, 2021). According to the report of the US Federal Trade Commission (FTC), the number of people defrauded on social media in 2021 is more than 95,000. It is also noteworthy that the number of these people between the ages of 18-39 is 2 times more than the older victims (Probasco, 2022). A study conducted in India also revealed that the number of reported cybercrime complaints based on abuse of social media platforms doubled in 2021 compared to 2020 (Shinde, 2022). According to the information Cihan and Y1ldiz (2021) obtained from the accessible website of the Court of Cassation in Turkey; between 2016-2019, the number of files related to crimes committed on social media is 953 and the number of crimes is 1139 .

Unfortunately, 95\% of cybersecurity problems are caused by human error (Cybint, 2020). Moreover, McAfee Enterprise and FireEye companies define social media as a very successful channel for targeting individuals in their 2022 cyber threat forecasts (Sharma, 2021). Social media users, especially those who unaware of their online safety, are the low hanging fruit that cybercriminals can easily pick (Cabral, 2022). Therefore, if social networks are used by teachers' personal development, professional development and learning and teaching platforms, they should have security awareness, knowledge and skills in social networks. In the literature, there are studies on social networking attitudes, behaviors, educational uses, and their competencies with teachers (Carpenter \& Krutka, 2015; Carter, 2020; Hutchison \& Wang, 2012; Mozhaevaa et al., 2014; Nochumson, 2020; Rashid et al., 2016; Trust \& Prestridge, 2021; Yaylak \& İnan, 2018), teacher candidates (Akuzum \& Ucar, 2015; Cam, 2012; Celik et al., 2015; Damico \& Krutka, 2018; Topal \& Akgun, 2015; Trytten, 2018) and adults (Alpert, 2020; Cakir, 2020; Genden, 2015; Lee \& Sin Sing, 2013; Sturkenboom, 2020). However, there is no study that determines the security awareness of teachers' candidates directly on social networks. It is thought that the research will close this gap in the field writing and that the results to be obtained can lead to teachers and teacher candidates' training on the subject.

The aim of this study is to investigate the level of safe social network usage of teacher candidates and to demonstrate whether the status of using secure social networking varies according to demographic variables.

The sub-objectives developed to accomplish the purpose of the study are stated below.

1. What are teacher candidates' levels of using safe social networking?

2. Is there a significant difference in teacher candidates' levels of using safe social networks according to some variables such as their gender, department, the use of licensed antivirus, etc. ?

\section{Method}

\subsection{Research Design}

The corrrelational descriptive model, one of the quantitative paradigms, was used within the study. Corrrelational descriptive model aims to determine the relationships between two or more variables or the level of these relationships (Buyukozturk et al., 2011; Cohen, Manion \& Morrison, 2000). Taking the study aim into account, this research design has been adopted by the researchers. 


\subsection{Participants}

The study group consisted of teacher candidates from a state university, Faculty of Education in Turkey. A total of 472 teacher candidates studying in the 3rd and 4th grades participated in the study. Since some of the teacher candidates who participated in the study filled in the measurement tool incompletely, the form filled by 456 teacher candidates were analyzed. The study group comprised of 333 (73\%) female and $123(27 \%)$ students.

\subsection{Data Collection Tools}

Safe Social Networking Scale [SSNS] and Personal Information Form were used to collect data. SSNS (Tosun \& Gecer, 2022) consists of 28 items and 5 sub-factors, which are Timeline/wall shares, Social network profile information and security of shares, Social network friend list and security, Social network login Information security, and Secure login to social network account. It is a five-point Likert scale ranging from "do not agree at all" (1) to "totally agree" (5). In this study, values of the model obtained in the CFA analysis were examined and the minimum Chi-squared value $\left(\chi^{2}=1218.38, d f=340, p=0.00\right)$ was observed to be meaningful. When the goodness of fit indices have been found to be as follows: RMSEA=.094, GFI=.89, AGFI=.87, CFI=.94, NFI =.87, $\mathrm{NNFI}=.89$, and SRMR $=.07$. The acceptable criteria for the goodness of fit indices examined indicate that the five-factor model obtained from the CFA is compatible and that the scale is validated. To determine the reliability of SSNS, the Cronbach alpha internal consistency coefficient was checked, and it has been found to be .73 for the whole scale. The increase in the scores obtained from the sub-dimensions of SSNS and from the overall scale scores indicates the use of high safe social networks. The five-factor structure obtained from the SSNS can be evaluated as five separate scales, and a total score of using the safe social network can be obtained from the scale.

Personal Information Form prepared by the researchers includes multiple choice questions aimed at determining the demographic information of the teacher candidates and the habits of using social networking.

\subsection{Data Analysis}

SPSS 18.0 software was used to analyze the study data. Frequency (f), percentage (\%) and arithmetic mean $(\bar{X})$ were used to describe the data within the descriptive statistics. The study data have been found to be normally distributed according to the skewness and kurtosis values remaining in between -2 and 2 . The data were analyzed through the use of $t$-tests and ANOVA.

\section{Results}

\subsection{Backgrounds of Teacher Candidates}

The findings regarding the demographic characteristics of teacher candidates participating in the study are presented in Table 1.

Once Table 1 has been analyzed, it is seen that $73 \%$ of teacher candidates are female, and $27 \%$ are male. $25.4 \%$ are enrolled at Science education department, 21.1\% English education, 20.6\% Turkish education, $17.5 \%$ in Primary education and $15.4 \%$ IT education. While $56.4 \%$ of teacher candidates are third-year students, $43.6 \%$ of them are fourth-year students. 
Table 1

Demographic characteristics of the respondents

\begin{tabular}{|c|c|c|}
\hline $\begin{array}{l}\text { Gender } \\
\text { Female } \\
\text { Male }\end{array}$ & $\begin{array}{c}\mathrm{n} \\
333 \\
123\end{array}$ & $\begin{array}{c}\% \\
73 \\
27\end{array}$ \\
\hline \multicolumn{3}{|l|}{ Having a licensed anti-virus software } \\
\hline Yes & 102 & 22.4 \\
\hline No & 354 & 77.6 \\
\hline \multicolumn{3}{|c|}{ Took courses on safe and informed social networking } \\
\hline Yes & 102 & 22.4 \\
\hline No & 354 & 77.6 \\
\hline \multicolumn{3}{|c|}{ Being self-sufficient to use social networks consciously and safely } \\
\hline Yes & 225 & 49.4 \\
\hline No & 73 & 16.0 \\
\hline I am not sure & 158 & 34.6 \\
\hline \multicolumn{3}{|l|}{ Number of social network accounts } \\
\hline $1-3$ & 124 & 27.2 \\
\hline $4-6$ & 275 & 60.3 \\
\hline 7 and more & 57 & 12.5 \\
\hline \multicolumn{3}{|c|}{$\begin{array}{l}\text { Having sufficient information about the privacy policy, terms of use and certain } \\
\text { conditions of the social networks used }\end{array}$} \\
\hline Yes & 99 & 21.7 \\
\hline No & 87 & 19.1 \\
\hline I am not sure & 270 & 59.2 \\
\hline \multicolumn{3}{|l|}{ Period of making security settings } \\
\hline I never do & 71 & 15.6 \\
\hline When social networking software give alerts & 5 & 1.1 \\
\hline Periodically on specific days and hours & 250 & 54.8 \\
\hline When I want to & 130 & 28.5 \\
\hline \multicolumn{3}{|l|}{ Time spent on social networks in one day (hour) } \\
\hline Less than 1 hour & 40 & 8.8 \\
\hline 1-3 hours & 232 & 50.9 \\
\hline 4-6 hours & 146 & 32.0 \\
\hline 7 hours and above & 38 & 8.3 \\
\hline \multicolumn{3}{|c|}{ Having sufficient knowledge about the law on the protection of personal data } \\
\hline Yes & 106 & 23.2 \\
\hline No & 121 & 26.5 \\
\hline I am not sure & 229 & 50.2 \\
\hline \multicolumn{3}{|l|}{ Department } \\
\hline Primary education & 80 & 17.5 \\
\hline Information technology education & 70 & 15.4 \\
\hline Turkish education & 94 & 20.6 \\
\hline English education & 96 & 21.1 \\
\hline Science education & 116 & 25.4 \\
\hline \multicolumn{3}{|l|}{ Social network experience (years) } \\
\hline $1-3$ & 29 & 6.4 \\
\hline $4-6$ & 159 & 34.9 \\
\hline 7-9 & 169 & 37.1 \\
\hline 10 years and over & 99 & 21.7 \\
\hline \multicolumn{3}{|l|}{ Owned social network accounts } \\
\hline Facebook & 274 & 60.1 \\
\hline Twitter & 248 & 54.4 \\
\hline Youtube & 319 & 70.0 \\
\hline Google+ & 284 & 62.3 \\
\hline Instagram & 387 & 84.9 \\
\hline Whatsapp & 442 & 96.9 \\
\hline
\end{tabular}




\subsection{Teacher Candidates' Levels of Using Safe Social Networks}

The results obtained from the analysis of teacher candidates' safe social network usage levels are presented in Table 2 .

Table 2

Safe social networking usage levels of teacher candidates

\begin{tabular}{llccc}
\hline Factor No & Sub-factors & $n$ & Mean & SD \\
\hline 1 & Posts on the timeline/wall. & & 4.62 & 0.48 \\
2 & Profile information on social network and & 3.72 & 0.97 \\
& security of posts. & & 4.01 & 0.86 \\
3 & Friend list and security of the social network. & 456 & 2.76 & 1.13 \\
4 & Social network login information security & & 3.44 & 0.90 \\
5 & Secure login to social network account & & 3.93 & 0.44 \\
\cline { 2 - 5 } Total & SSNS & & & \\
\hline
\end{tabular}

According to Table 2, behaviors towards "social network access information security", which is the fourth factor under SSNS, were moderate, while all other sub-factors were quite high. It is also remarkable that the total score of SSNS was found to be high. Based on the results in Table 2, it is to say that teacher candidates perform a high level of safe social network usage behaviors when using social networks.

\subsection{Effects of Demographic Factors on Safe Social Network}

In the context of the other research question, the social network usage levels of teacher candidates were examined in terms of demographic factors. First, we examined whether the gender variable have an effect on the safe social network usage levels of the participants. The results obtained are given in Table 3.

Table 3

Results of teacher candidates' SSNS behavior according to gender

\begin{tabular}{|c|c|c|c|c|c|c|}
\hline SSNS & Gender & $n$ & Mean & $S D$ & $t$ & $p$ \\
\hline \multirow{2}{*}{$1^{\text {st }}$ factor } & Female & 333 & 4.66 & 0.45 & \multirow{2}{*}{3.20} & \multirow{2}{*}{0.001} \\
\hline & Male & 123 & 4.50 & 0.54 & & \\
\hline \multirow{2}{*}{$2^{\text {nd }}$ factor } & Female & 333 & 3.86 & 0.91 & \multirow{2}{*}{5.05} & \multirow{2}{*}{0.000} \\
\hline & Male & 123 & 3.35 & 1.04 & & \\
\hline \multirow{2}{*}{$3^{\text {rd }}$ factor } & Female & 333 & 4.06 & 0.82 & \multirow{2}{*}{2.02} & \multirow{2}{*}{0.044} \\
\hline & Male & 123 & 3.88 & 0.94 & & \\
\hline \multirow{2}{*}{$4^{\text {th }}$ factor } & Female & 333 & 2.84 & 1.15 & \multirow{2}{*}{2.69} & \multirow{2}{*}{0.007} \\
\hline & Male & 123 & 2.52 & 1.07 & & \\
\hline \multirow{2}{*}{$5^{\text {th }}$ factor } & Female & 333 & 3.45 & 0.84 & \multirow{2}{*}{0.24} & \multirow{2}{*}{0.807} \\
\hline & Male & 123 & 3.43 & 1.04 & & \\
\hline \multirow{2}{*}{ Total } & Female & 333 & 3.99 & 0.41 & \multirow{2}{*}{5.05} & \multirow{2}{*}{0.000} \\
\hline & Male & 123 & 3.76 & 0.48 & & \\
\hline
\end{tabular}

According to Table 3, significant differences were found in all sub-factors and total scale averages except factor 5 . In the first factor, a significant difference was observed between the mean scores $[t(454)=3.20, p<.001]$. The average scores of females were found to be higher than males. In other words, females behave more carefully than males while sharing the timeline/wall. Also, a significant difference in factor $2[t(454)=5.05 ; p<.001]$ was found in terms of gender. Similarly, females were found to be more careful about social network profile information and the security of the shares. In the third factor, a significant difference was found at 0.05 level $[t(454)=2.02$; $p<.05]$. When the averages are examined, it was found that females were more cautious in social network friend list and security behaviors than males. The fourth factor was related to social network access information security behaviors, a significant difference was observed $[t(454)=2.69 ; p<.01]$. In other saying, females care more about the security of social network 
login information than males. Factor 5 includes behaviors related to secure login to social network account. No significant difference was found in this factor in terms of gender. There is also a significant difference in the total score of the scale $[t(454)=5.05 ; p<.001]$. As a final remark, the mean SSNS score of female was higher than that of male.

As another step, analyzes were conducted to determine whether departments of teacher candidates effect was a variable on their safe social networking usage levels. The results are presented in Table 4.

Table 4

Results of teacher candidates' SSNS behavior according to their department

\begin{tabular}{|c|c|c|c|c|c|}
\hline & Mean & $S D$ & $F$ & $p$ & $\begin{array}{r}\text { Intergroup } \\
\text { difference }\end{array}$ \\
\hline \multicolumn{6}{|l|}{$1^{\text {st }}$ factor } \\
\hline Primary education & 4.67 & 0.49 & \multirow{5}{*}{3.13} & \multirow{5}{*}{0.015} & \multirow{5}{*}{$\begin{array}{l}1-4 ; 2-4 ; \\
3-4 ; 4-5\end{array}$} \\
\hline IT education & 4.70 & 0.35 & & & \\
\hline Turkish education & 4.67 & 0.41 & & & \\
\hline English education & 4.48 & 0.56 & & & \\
\hline Science education & 4.61 & 0.52 & & & \\
\hline \multicolumn{6}{|l|}{$2^{\text {nd }}$ factor } \\
\hline Primary education & 3.82 & 0.81 & \multirow{5}{*}{2.88} & \multirow{5}{*}{0.022} & \multirow{5}{*}{$\begin{array}{l}1-4 ; 2-5 \\
3-4 ; 4-5\end{array}$} \\
\hline IT education & 3.59 & 0.88 & & & \\
\hline Turkish education & 3.78 & 1.17 & & & \\
\hline English education & 3.49 & 0.94 & & & \\
\hline Science education & 3.89 & 0.99 & & & \\
\hline \multicolumn{6}{|l|}{$3^{\text {rd }}$ factor } \\
\hline Primary education & 4.03 & 1.31 & \multirow{5}{*}{2.96} & \multirow{5}{*}{0.019} & \multirow{5}{*}{$2-4 ; 2-5$} \\
\hline IT education & 4.27 & 1.46 & & & \\
\hline Turkish education & 4.03 & 0.85 & & & \\
\hline English education & 3.81 & 0.89 & & & \\
\hline Science education & 3.99 & 0.75 & & & \\
\hline \multicolumn{6}{|l|}{$4^{\text {th }}$ factor } \\
\hline Primary education & 2.89 & 1.28 & \multirow{5}{*}{1.13} & \multirow{5}{*}{0.340} & \multirow{5}{*}{-} \\
\hline IT education & 2.69 & 1.08 & & & \\
\hline Turkish education & 2.71 & 1.15 & & & \\
\hline English education & 2.61 & 1.20 & & & \\
\hline Science education & 2.88 & 1.13 & & & \\
\hline \multicolumn{6}{|l|}{$5^{\text {th }}$ factor } \\
\hline Primary education & 3.31 & 0.65 & \multirow{5}{*}{1.42} & \multirow{5}{*}{0.223} & \multirow{5}{*}{-} \\
\hline IT education & 3.61 & 0.68 & & & \\
\hline Turkish education & 3.35 & 0.67 & & & \\
\hline English education & 3.47 & 0.68 & & & \\
\hline Science education & 3.50 & 0.92 & & & \\
\hline \multicolumn{6}{|l|}{ Overall } \\
\hline Primary education & 3.96 & 0.16 & \multirow{5}{*}{3.30} & \multirow{5}{*}{0.011} & \multirow{5}{*}{$\begin{array}{l}1-4 ; 2-4 \\
3-4 ; 4-5\end{array}$} \\
\hline IT education & 3.99 & 0.15 & & & \\
\hline Turkish education & 3.94 & 0.16 & & & \\
\hline English education & 3.79 & 0.14 & & & \\
\hline Science education & 3.98 & 0.16 & & & \\
\hline
\end{tabular}

As summarized in Table 4, significant differences were found between departments in all subfactors and overall scores of SSNS, except the $4^{\text {th }}$ and $5^{\text {th }}$ factors. In terms of the first factor, Timeline/Wall Shares, a significant difference were found among departments $\left[F_{(4-451)}=3.13\right.$; $p<0.01]$. The averages scores revealed that the scores of IT education department was higher than the other departments. The arithmetic mean of English education was found to be lower than other departments. In the context of the second factor, Social Network profile information and security of 
shares, significant difference was found on the basis of the department $\left[F_{(4,451)}=2.88 ; p<0.05\right]$. In this factor, the average of the department of Science education was found to be higher than other departments, whereas the average of English education was lower than others.

With regard the third factor, Friend list and security of the social network, as with other factors, significant difference was found between the departments. $\left[F_{(4,451)}=2.96 ; p<0.01\right]$. According to the average scores of the departments, IT education department was found to be higher than the others. The department of Turkish education and primary education department followed the department of IT education. In other words, teacher candidates enrolled at these departments exhibit conscious behaviors regarding social network friends list and security.

In terms of departments, no significant differences were found in fourth (Social network login information security) and fifth (Secure login to the social network account) factors. Considering the scale as a whole, significant difference were found among of departments in SSNS total scores $\left(F_{(4,451)}=3.30 ; p<0.01\right)$. The average scores showed that students at IT teaching department received the highest average, followed by Science education, Primary education, Turkish education and English education.

To determine whether the levels of safe social network use of teacher trainees differ according to their use of licensed anti-virus software, t-tests were conducted. The results are as presented in Table 5 .

Table 5

SSNS behavior of teacher candidates according to having licensed antivirus

\begin{tabular}{|c|c|c|c|c|c|c|}
\hline SSNS & $\begin{array}{c}\text { Having } \\
\text { Licensed } \\
\text { Antivirus }\end{array}$ & $n$ & Mean & $S D$ & $t$ & $p$ \\
\hline \multirow{2}{*}{$1^{\text {st }}$ factor } & Yes & 204 & 4.65 & 0.46 & \multirow{2}{*}{1.25} & \multirow{2}{*}{0.210} \\
\hline & No & 252 & 4.59 & 0.50 & & \\
\hline \multirow{2}{*}{$2^{\text {nd }}$ factor } & Yes & 204 & 3.77 & 0.96 & \multirow{2}{*}{0.85} & \multirow{2}{*}{0.394} \\
\hline & No & 252 & 3.69 & 0.98 & & \\
\hline \multirow{2}{*}{$3^{\text {rd }}$ factor } & Yes & 204 & 4.11 & 0.84 & \multirow{2}{*}{2.34} & \multirow{2}{*}{0.020} \\
\hline & No & 252 & 3.92 & 0.87 & & \\
\hline \multirow{2}{*}{$4^{\text {th }}$ factor } & Yes & 204 & 2.87 & 1.09 & \multirow{2}{*}{2.44} & \multirow{2}{*}{0.015} \\
\hline & No & 252 & 2.50 & 0.95 & & \\
\hline \multirow{2}{*}{$5^{\text {th }}$ factor } & Yes & 204 & 3.66 & 0.89 & \multirow{2}{*}{4.64} & \multirow{2}{*}{0.000} \\
\hline & No & 252 & 3.27 & 0.87 & & \\
\hline \multirow{2}{*}{ Total } & Yes & 204 & 3.99 & 0.43 & \multirow{2}{*}{2.52} & \multirow{2}{*}{0.012} \\
\hline & No & 252 & 3.88 & 0.45 & & \\
\hline
\end{tabular}

When examining the use of licensed antivirus of teacher candidates' SSNU behaviors, no significant difference between $1^{\text {st }}$ factor (time tunnel / wall shares) and $2^{\text {nd }}$ factor (Social network profile information and security of shares) was found. Significant differences were found in the $3^{\text {rd }}$ factor (Social network friends list and security) $[t(454)=2.34 ; p<.05], 4^{\text {th }}$ factor (Social network login information security) $[t(454)=2,44 ; p<.01]$, $5^{\text {th }}$ factor (Secure login to social network account) $[t(454)=4.64 ; p<.001]$ and total scale scores $[t(454)=2.52 ; p<.05]$. Considering the average scores, the SSNU behaviors of participants using licensed antivirus have been seen to be higher than those that do not use licensed antivirus software.

The analyzes were also conducted to determine whether the teachers' candidate levels of using safe social network differed according to the status of taking courses for secure and conscious social network use. The results are as presented in Table 6. 
Table 6

Teacher candidates' SSNS behavior according to the course they took for secure and conscious social network

\begin{tabular}{|c|c|c|c|c|c|c|}
\hline SSNS & Taken courses & $n$ & Mean & $S D$ & $t$ & $p$ \\
\hline \multirow{2}{*}{$1^{\text {st }}$ factor } & Yes & 102 & 4.71 & 0.32 & \multirow{2}{*}{2.29} & \multirow{2}{*}{0.022} \\
\hline & No & 354 & 4.59 & 0.52 & & \\
\hline \multirow{2}{*}{$2^{\text {nd }}$ factor } & Yes & 102 & 3.78 & 1.06 & \multirow{2}{*}{0.69} & \multirow{2}{*}{0.490} \\
\hline & No & 354 & 3.71 & 0.96 & & \\
\hline \multirow{2}{*}{$3^{\text {rd }}$ factor } & Yes & 102 & 4.12 & 0.78 & \multirow{2}{*}{1.47} & \multirow{2}{*}{0.142} \\
\hline & No & 354 & 3.98 & 0.88 & & \\
\hline \multirow{2}{*}{$4^{\text {th }}$ factor } & Yes & 102 & 2.78 & 1.13 & \multirow{2}{*}{0.64} & \multirow{2}{*}{0.521} \\
\hline & No & 354 & 2.69 & 1.16 & & \\
\hline \multirow{2}{*}{$5^{\text {th }}$ factor } & Yes & 102 & 3.68 & 0.82 & \multirow{2}{*}{2.95} & \multirow{2}{*}{0.003} \\
\hline & No & 354 & 3.38 & 0.91 & & \\
\hline \multirow{2}{*}{ Total } & Yes & 102 & 4.03 & 0.41 & \multirow{2}{*}{2.52} & \multirow{2}{*}{0.012} \\
\hline & No & 354 & 3.90 & 0.45 & & \\
\hline
\end{tabular}

When teacher candidates' SSNS behaviors were considered their experience of taking course regarding the secure and conscious social network usage, significant differences were found in $1^{\text {st }}$ factor $\left(t(454=2.29 ; p<.05), 5^{\text {th }}\right.$ factor $(t(454=2.95 ; p<.01)$ and total scale scores $(t(454=2.52 ; p<.05)$. These results reveal that participants who took courses related to the use a secure and conscious social network have higher SSNU bejaviour than those who did not take.

In the text stage, analyzes were conducted to determine whether the levels of SSNU of teacher candidates differed according to their knowledge about privacy policy, terms of use and special conditions of social networks used. The results are presented in Table 7.

Table 7

Effect of teacher candidates' privacy policy, terms of use and special conditions of social networks knowledge on their SSNS behavior

\begin{tabular}{|c|c|c|c|c|c|}
\hline & Mean $H K^{*}$ & $S D$ & $F$ & $p$ & $\begin{array}{l}\text { Intergroup } \\
\text { difference }\end{array}$ \\
\hline \multicolumn{6}{|l|}{$1^{\text {st }}$ factor } \\
\hline Yes & 4.71 & 0.41 & \multirow{3}{*}{5.87} & \multirow{3}{*}{0.003} & \multirow{3}{*}{$1-2 ; 2-3$} \\
\hline No & 4.47 & 0.60 & & & \\
\hline Not sure & 4.63 & 0.46 & & & \\
\hline \multicolumn{6}{|l|}{$2^{\text {nd }}$ factor } \\
\hline Yes & 3.82 & 1.01 & \multirow{3}{*}{1.06} & \multirow{3}{*}{0.346} & \multirow{3}{*}{-} \\
\hline No & 3.61 & 1.01 & & & \\
\hline Not sure & 3.73 & 0.94 & & & \\
\hline \multicolumn{6}{|l|}{$3^{\text {rd }}$ factor } \\
\hline Yes & 4.13 & 0.94 & \multirow{3}{*}{2.39} & \multirow{3}{*}{0.093} & \multirow{3}{*}{-} \\
\hline No & 3.85 & 0.82 & & & \\
\hline Not sure & 4.02 & 0.83 & & & \\
\hline \multicolumn{6}{|l|}{$4^{\text {th }}$ factor } \\
\hline Yes & 2.62 & 1.26 & \multirow{3}{*}{1.28} & \multirow{3}{*}{0.277} & \multirow{3}{*}{-} \\
\hline No & 2.71 & 1.12 & & & \\
\hline Not sure & 2.82 & 1.09 & & & \\
\hline \multicolumn{6}{|l|}{$5^{\text {th }}$ factor } \\
\hline Yes & 3.98 & 0.90 & \multirow{3}{*}{28.72} & \multirow{3}{*}{0.000} & \multirow{3}{*}{$\begin{array}{c}1-2 ; 1-3 \\
2-3\end{array}$} \\
\hline No & 3.08 & 1.01 & & & \\
\hline Not sure & 3.37 & 0.77 & & & \\
\hline \multicolumn{6}{|l|}{ Overall } \\
\hline Yes & 4.08 & 0.46 & \multirow{3}{*}{12.56} & \multirow{3}{*}{0.000} & \multirow{3}{*}{$\begin{array}{l}1-4 ; 2-4 \\
3-4 ; 4-5\end{array}$} \\
\hline No & 3.76 & 0.45 & & & \\
\hline Not sure & 3.98 & 0.41 & & & \\
\hline
\end{tabular}

${ }^{*}$ Note: Mean scores of perception of having sufficient knowledge on the privacy policy, terms of use and special conditions of the social networks used 
As a result of the analysis conducted whether there are differences of the levels of the use of safe social network of teacher candidates based on their status of sufficiently knowledgeable on the private privacy, terms of use and special conditions, significant differences are found in $1^{\text {st }}$ factor $\left[F_{(2,453)}=5.87 ; p<0.01\right], 5^{\text {th }}$ factor $\left[F_{(2,453)}=28.72 ; p<0.001\right]$ and SSNS total scores $\left[F_{(2,453)}=12.56 ; p<0.001\right]$. In terms of first and fifth factors, those who claim that they have sufficient knowledge on the on the private privacy, terms of use and special conditions received higher scores than those who indicated either having not sufficiently knowledge or not sure.

In terms of having knowledge on the law on protection of personal data variable, it was examined whether this variable was a factor on the levels of SSNU of teacher candidates. The results are as presented in Table 8.

Table 8

Effect of teacher candidates' law on protection of personal data knowledge on their SSNS behavior

\begin{tabular}{|c|c|c|c|c|c|}
\hline & Mean $H K^{*}$ & $S D$ & $F$ & $p$ & $\begin{array}{l}\text { Intergroup } \\
\text { difference }\end{array}$ \\
\hline \multicolumn{6}{|l|}{$1^{\text {st }}$ factor } \\
\hline Yes & 4.69 & 0.39 & \multirow{3}{*}{2.94} & \multirow{3}{*}{0.054} & \multirow{3}{*}{$1-2$} \\
\hline No & 4.53 & 0.55 & & & \\
\hline Not sure & 4.63 & 0.48 & & & \\
\hline \multicolumn{6}{|l|}{$2^{\text {nd }}$ factor } \\
\hline Yes & 3.76 & 1.00 & \multirow{3}{*}{0.59} & \multirow{3}{*}{0.552} & \multirow{3}{*}{-} \\
\hline No & 3.64 & 0.96 & & & \\
\hline Not sure & 3.74 & 0.96 & & & \\
\hline \multicolumn{6}{|l|}{$3^{\text {rd }}$ factor } \\
\hline Yes & 4.17 & 0.89 & \multirow{3}{*}{5.46} & \multirow{3}{*}{0.005} & \multirow{3}{*}{$1-2 ; 2-3$} \\
\hline No & 3.81 & 0.87 & & & \\
\hline Not sure & 4.04 & 0.82 & & & \\
\hline \multicolumn{6}{|l|}{$4^{\text {th }}$ factor } \\
\hline Yes & 2.75 & 1.29 & \multirow{3}{*}{0.59} & \multirow{3}{*}{0.552} & \multirow{3}{*}{-} \\
\hline No & 2.66 & 1.00 & & & \\
\hline Not sure & 2.68 & 1.12 & & & \\
\hline \multicolumn{6}{|l|}{$5^{\text {th }}$ factor } \\
\hline Yes & 3.88 & 0.88 & \multirow{3}{*}{22.67} & \multirow{3}{*}{0.000} & \multirow{3}{*}{$\begin{array}{c}1-2 ; 2-3 ; \\
1-3\end{array}$} \\
\hline No & 3.11 & 0.95 & & & \\
\hline Not sure & 3.42 & 0.79 & & & \\
\hline \multicolumn{6}{|l|}{ Overall } \\
\hline Yes & 4.05 & 0.44 & \multirow{3}{*}{10.14} & \multirow{3}{*}{0.000} & \multirow{3}{*}{$\begin{array}{c}1-2 ; 2-3 \\
1-3\end{array}$} \\
\hline No & 3.79 & 0.43 & & & \\
\hline Not sure & 3.95 & 0.43 & & & \\
\hline
\end{tabular}

${ }^{*}$ Note: Mean scores of perception of having sufficient knowledge about the law on protection of personal data

According to the results in Table 8, significant differences are observed in $1^{\text {st }}$ factor $\left[F_{(2,453)}=2.94 ; p<0.05\right], 3^{\text {rd }}$ factor $\left[F_{(2,453)}=5.46 ; p<0.01\right], 5^{\text {th }}$ factor $\left[F_{(2,453)}=22.67\right.$; $p<0.001]$ and SSNS total scores $\left[F_{(2,453)}=10.14 ; p<0.001\right]$. When the means of $1^{\text {st }}, 3^{\text {rd }}, 5^{\text {th }}$ factors and SSNS scale are considered, those who claim of having sufficient knowledge on the law on protection of personal data got higher scores than the ones claim of having no sufficient knowledge or being not sure.

As another variable, it was determined whether teacher candidates' levels differed according to their perceptipion of sufficiency on the secure and conscious social network use. The analysis results are presened in Table 9. 
Table 9

Effect of teacher candidates' secure and conscious social network use knowledge on their SSNS behavior

\begin{tabular}{|c|c|c|c|c|c|}
\hline & Mean $H K^{*}$ & $S D$ & $F$ & $p$ & $\begin{array}{l}\text { Intergroup } \\
\text { difference }\end{array}$ \\
\hline \multicolumn{6}{|l|}{$1^{\text {st }}$ factor } \\
\hline Sufficient & 4.66 & 0.45 & \multirow{3}{*}{1.97} & \multirow{3}{*}{0.140} & \multirow{3}{*}{-} \\
\hline Not sufficient & 4.56 & 0.48 & & & \\
\hline Not sure & 4.58 & 0.53 & & & \\
\hline \multicolumn{6}{|l|}{$2^{\text {nd }}$ factor } \\
\hline Sufficient & 3.70 & 1.03 & \multirow{3}{*}{1.42} & \multirow{3}{*}{0.242} & \multirow{3}{*}{-} \\
\hline Not sufficient & 3.60 & 1.02 & & & \\
\hline Not sure & 3.62 & 0.85 & & & \\
\hline \multicolumn{6}{|l|}{$3^{\text {rd }}$ factor } \\
\hline Sufficient & 4.07 & 0.91 & \multirow{3}{*}{2.93} & \multirow{3}{*}{0.054} & \multirow{3}{*}{$1-2$} \\
\hline Not sufficient & 3.79 & 0.82 & & & \\
\hline Not sure & 3.02 & 0.79 & & & \\
\hline \multicolumn{6}{|l|}{$4^{\text {th }}$ factor } \\
\hline Sufficient & 2.85 & 1.19 & \multirow{3}{*}{1.40} & \multirow{3}{*}{0.245} & \multirow{3}{*}{-} \\
\hline Not sufficient & 2.67 & 1.09 & & & \\
\hline Not sure & 2.69 & 1.07 & & & \\
\hline \multicolumn{6}{|l|}{$5^{\text {th }}$ factor } \\
\hline Sufficient & 3.58 & 0.93 & \multirow{3}{*}{6.52} & \multirow{3}{*}{0.002} & \multirow{3}{*}{$1-2 ; 1-3$} \\
\hline Not sufficient & 3.17 & 0.99 & & & \\
\hline Not sure & 3.38 & 0.77 & & & \\
\hline \multicolumn{6}{|l|}{ Overall } \\
\hline Sufficient & 3.97 & 0.44 & \multirow{3}{*}{3.25} & \multirow{3}{*}{0.040} & \multirow{3}{*}{$1-2 ; 2-3$} \\
\hline Not sufficient & 3.81 & 0.47 & & & \\
\hline Not sure & 3.94 & 0.42 & & & \\
\hline
\end{tabular}

The results revealed that teacher candidates' levels of using secure social networks differ according to their perception of having sufficient knowledge on the use social networks consciously and securely. In terms of factors, statistical differences were found at $3^{\text {rd }}$ factor $\left[F_{(2,453)}=2.93 ; p<0.05\right]$, $5^{\text {th }}$ factor $\left[F_{(2,453)}=6.52 ; p<0.01\right]$, and total scores of SSNS $\left[F_{(2,453)}=3.25 ; p<0.05\right]$. In these factors and total scores, it was seen that the mean scores of those who find themselves sufficient to use social networks consciously and securely is higher than those who describe themselves as not sufficient and those are not sure.

Table 10 shows the results of the level of use of the safe social networks of the teacher candidates with the rate of time spent on social networks (daily).

Table 10

Level of safe social networking of teacher candidates' in terms of daily time spent on social networks

\begin{tabular}{llcccc}
\hline & Mean & $S D$ & $F$ & $p$ & $\begin{array}{c}\text { Intergroup } \\
\text { difference }\end{array}$ \\
\hline $\begin{array}{l}\text { 1st factor } \\
\quad \text { Less than 1 hour }\end{array}$ & 47.45 & 3.04 & & & \\
$\quad$ 1-3 hours & 46.31 & 4.60 & 1.25 & 0.288 & \\
$\quad$ 4-6 hours & 45.79 & 5.64 & & & \\
$\quad 7$ hours and above & 46.08 & 4.88 & & & \\
$2^{\text {nd }}$ factor & & & & & \\
$\quad$ Less than 1 hour & 25.33 & 5.71 & & & \\
$\quad$ 1-3 hours & 22.21 & 5.75 & 4.62 & & \\
4-6 hours & 21.62 & 5.99 & & & \\
$\quad 7$ hours and above & 23.18 & 5.17 & & & \\
\hline
\end{tabular}


Table 10 continued

\begin{tabular}{|c|c|c|c|c|c|}
\hline & Mean & $S D$ & $F$ & $p$ & $\begin{array}{l}\text { Intergroup } \\
\text { difference }\end{array}$ \\
\hline \multicolumn{6}{|l|}{$3^{\text {rd }}$ factor } \\
\hline Less than 1 hour & 16.63 & 4.66 & \multirow{4}{*}{0.49} & \multirow{4}{*}{0.684} & \multirow{4}{*}{-} \\
\hline 1-3 hours & 16.09 & 4.56 & & & \\
\hline 4-6 hours & 15.89 & 4.58 & & & \\
\hline 7 hours and above & 15.92 & 3.22 & & & \\
\hline \multicolumn{6}{|l|}{$4^{\text {th }}$ factor } \\
\hline Less than 1 hour & 10.00 & 3.77 & \multirow{4}{*}{4.99} & \multirow{4}{*}{0.002} & \multirow{4}{*}{$1-2 ; 1-3$} \\
\hline 1-3 hours & 8.19 & 3.36 & & & \\
\hline $4-6$ hours & 8.28 & 3.24 & & & \\
\hline 7 hours and above & 7.13 & 3.50 & & & \\
\hline \multicolumn{6}{|l|}{$5^{\text {th }}$ factor } \\
\hline Less than 1 hour & 17.05 & 4.73 & \multirow{4}{*}{0.67} & \multirow{4}{*}{0.567} & \multirow{4}{*}{-} \\
\hline $1-3$ hours & 17.50 & 4.27 & & & \\
\hline 4-6 hours & 17.11 & 4.67 & & & \\
\hline 7 hours and above & 16.47 & 5.16 & & & \\
\hline \multicolumn{6}{|l|}{ Overall } \\
\hline Less than 1 hour & 116.45 & 11.67 & \multirow{4}{*}{4.31} & \multirow{4}{*}{0.005} & \multirow{4}{*}{$\begin{array}{c}\text { 1-2; 1-3; } \\
1-4\end{array}$} \\
\hline 1-3 hours & 110.29 & 11.74 & & & \\
\hline 4-6 hours & 108.69 & 13.50 & & & \\
\hline 7 hours and above & 108.79 & 12.01 & & & \\
\hline
\end{tabular}

According to the results of the analysis, significant differences were found in the $2^{\text {nd }}$ factor $\left[F_{(3,452)}=4.62 ; p<0.01\right]$, the $4^{\text {th }}$ factor $\left[F_{(3-452)}=4.99 ; p<0.01\right]$ and the total scores of the SSNS $\left[F_{(3,452)}=4.31 ; p<0.01\right]$. Considering the related sub-factors and total scores, it can be stated teacher candidates who spend less than one hour in social networks use social networks more securely than those who spend 1-3 hours, 4-6 hours, and 7 hours or more.

Table 11 shows the results of the level of use of the safe social networks of the teacher candidates according to the number of social network accounts they have.

Table 11

Level of safe social networking of teacher candidates' in terms of number of social network accounts they use

\begin{tabular}{|c|c|c|c|c|c|}
\hline & Mean & $S D$ & $F$ & $p$ & $\begin{array}{l}\text { Intergroup } \\
\text { difference }\end{array}$ \\
\hline \multicolumn{6}{|l|}{$1^{\text {st }}$ factor } \\
\hline $1-3$ & 4.66 & 0.41 & \multirow{3}{*}{2.85} & \multirow{3}{*}{0.059} & \multirow{3}{*}{$1-2 ; 1-3$} \\
\hline $4-6$ & 4.56 & 0.51 & & & \\
\hline 7 and more & 4.58 & 0.51 & & & \\
\hline \multicolumn{6}{|l|}{$2^{\text {nd }}$ factor } \\
\hline $1-3$ & 4.18 & 0.82 & \multirow{3}{*}{22.99} & \multirow{3}{*}{0.000} & \multirow{3}{*}{$\begin{array}{c}1-2 ; 1-3 ; \\
2-3\end{array}$} \\
\hline $4-6$ & 3.61 & 0.97 & & & \\
\hline 7 and more & 3.28 & 0.94 & & & \\
\hline \multicolumn{6}{|l|}{$3^{\text {rd }}$ factor } \\
\hline $1-3$ & 4.03 & 0.85 & \multirow{3}{*}{1.25} & \multirow{3}{*}{0.286} & \multirow{3}{*}{-} \\
\hline $4-6$ & 3.97 & 0.87 & & & \\
\hline 7 and more & 4.17 & 0.81 & & & \\
\hline \multicolumn{6}{|l|}{$4^{\text {th }}$ factor } \\
\hline 1-3 & 3.05 & 1.14 & \multirow{3}{*}{8.05} & \multirow{3}{*}{0.000} & \multirow{3}{*}{$\begin{array}{c}1-2 ; 1-3 \\
2-3\end{array}$} \\
\hline $4-6$ & 2.71 & 1.12 & & & \\
\hline 7 and more & 2.36 & 1.07 & & & \\
\hline \multicolumn{6}{|l|}{$5^{\text {th }}$ factor } \\
\hline 1-3 & 3.44 & 0.88 & \multirow{3}{*}{4.68} & \multirow{3}{*}{0.010} & \multirow{3}{*}{$1-3 ; 2-3$} \\
\hline $4-6$ & 3.78 & 0.90 & & & \\
\hline 7 and more & 3.38 & 0.88 & & & \\
\hline
\end{tabular}


Table 11 continued

\begin{tabular}{lccccc}
\hline & Mean & $S D$ & $F$ & $p$ & $\begin{array}{c}\text { Intergroup } \\
\text { difference }\end{array}$ \\
\hline Overall & & & & & \\
$1-3$ & 4.09 & 0.40 & 11.36 & 0.000 & $1-2 ; 1-3$ \\
$4-6$ & 3.88 & 0.43 & & & \\
7 and more & 3.85 & 0.50 & & & \\
\hline
\end{tabular}

According to the results summarized in Table 11, teacher candidates' level of using safe social network in terms of the number of social networks they use, significant differences were found in the $1^{\text {st }}$ factor $\left[F_{(2,453)}=2.856 ; p<0.05\right], 2^{\text {nd }}$ factor $\left[F_{(2,453)}=22.99 ; p<0.001\right], 4^{\text {th }}$ factor $\left[F_{(2,453)}=8.05 ; p<0.001\right], 5^{\text {th }}$ factor $\left[F_{(2,453)}=4.68 ; p<0.05\right]$ and total scores of SSNS $\left[F_{(2,453)}=11.36 ; p<0.001\right]$. When the mean scores of these factors and SSNS total score are considered, social network account numbers 1-3 was found to have higher mean scores in the subfactors and total scale than those having accounts $4-6$ to 7 and above.

\section{Discussion and Conclusion}

The aim of this study was to investigate the levels of safe social networking of teacher candidates and also to reveal whether the status of using safe social networks differs according to demographic variables.

It has been revealed that a large part of teacher candidates do not share their social network passwords with anyone. Students are not likely to share their social network passwords with their parents also. It is understandable that teacher candidates do not share this specific information with their parents due to their age. Because the password is the most important weapon that protects individuals from digital threats and risks, passwords of the social network should be shared with anyone, regardless of their proximity. Creating different and special passwords for each environment that needs to be entered with the password, reproducing these passwords with certain periods, and not be shared with anyone will make this weapon unique and powerful (Ceyhan et al., 2015).

When looking at the social networks most commonly used by teacher candidates, Whatsapp, Instagram, and Youtube are at the top ranks. According to the Digital 2021 Global Overview Report, which includes the January 2021 data prepared by HootSuite and We Are Social firms; this ranking across the globe is Facebook, Youtube, and Whatsapp (Kemp, 2021a). According to another report obtained by the collaboration of HootSuite and We Are Social firms, the most widely used social networks in Turkey have been identified as Youtube, Instagram, and Whatsapp (Kemp, 2021b). The most widely used social network ranking of teacher trainees is similar to the data of the Digital 2021 report in Turkey. Among the reasons that teachers candidates use social networks, "Chatting with friends" is in the first place. The fact that interpersonal conversations can be easily done with Whatsapp, the most preferred smartphone application for social network connection resulted as Whatsapp which appears in the first place in the social network ranking that students prefer. In addition, Whatsapp is widely preferred for chat purposes, as it allows video and written chats, and protects messages with end-to-end encryption. Among the reasons students use social networking, it is noteworthy that they want to follow their teachers' announcements and course notes. In the literature, there are studies investigating the use of Whatsapp for educational purposes in higher education. According to the research conducted by Sebetci et al. (2018) with university students; it was seen that students preferred Whatsapp application frequently during the education process (85.7\%), homework/project studies (59.5\%), discussion of the subjects related to the course/homework (60.9\%), sharing (59.5\%) and asking questions (72.3\%). In the study of Gasaymeh (2017) with university students, students stated that Whatsapp's integration into education was easy, fun, and useful. Nitza and Roman (2016) also emphasized that Whatsapp groups lead to increased communication and cooperation among their members and can be used as a learning tool. 
Almost all the students preferred their smartphones to connect the social networks. The Digital 2021 Turkey Report reports 98.5\% smartphone use (Kemp, 2021b), which shows the highest preference for users in Turkey to connect to social networks. According to the Digital 2021, Global Overview Report, which includes the January 2021 data by HootSuite and We Are Social firms, 4.15 billion people out of 4.20 billion connect to social networks with their smartphones (Kemp, 2021a). This result can be said to be natural because of the wide range of smartphones offered to individuals as well as diversity, easy accessibility, availability, and usability. This result is also supported by students to have a minimum choice of internet cafes for social network access.

Half of the teacher candidates participating in the study stated that the time spent on social networks was between 1-3 hours on average per day. According to the January 2021 data, the average daily duration of users in Turkey on social networks was 2 hours and 57 minutes (Kemp, 2021b), while the worldwide use was 2 hours and 25 minutes (Kemp, 2021a).

Students' social networking friends list includes school friends, neighborhood friends, relatives, siblings, and teachers in the top five ranks. It is acceptable for teachers to take an important position in this ranking as an indication that students are using social networks for educational purposes. The number of students who have never really met with the people on the friend list is also undeniable.

Teacher candidates showed high levels of use of safe social networking. From the perspectives of sub-factors, the 4th factor's score "Social network login Information security", was moderate in behavior, while all other sub-factors have been seen to be quite high. In other words, teachers candidates are successful in the safe use of social networks. In a study conducted by Erdoğmuş (2017) with 550 university students, it was concluded that Internet Security Awareness was the most effective dimension on students' awareness about information security.

As a consequence of the analysis conducted on whether there is a difference according to gender in the behaviors of teacher candidates using the safe social network; significant differences were observed in all sub-factors and total scale averages, except for the fifth factor of secure access to the social network account. The female students' SSNS mean was higher than the males. In support of the findings, Akgun and Topal (2015) found that the information security awareness among female students was higher than that of male students. Ariturk (2015) revealed that female attitudes towards information security and knowledge awareness were higher than males. In some studies, it is stated that females are more concerned with the loss of privacy than males, perceived the severity of the negative consequences of the loss of privacy at higher levels, and were more concerned about privacy in online environments (Garbarino \& Strahilevitz, 2004; Hoy \& Milne, 2010; Youn \& Hall, 2008). In this research, the finding that females use safe social networks more carefully than males can be justified for the same reasons identified in the above studies.

As a consequence of the analysis conducted carried out on whether there is a difference in the levels of SSNU of teacher candidates according to departments significant differences were found between the departments in all sub-factors and total SSNS except the 4th factor (social network login information security) and the 5 th factor (secure login to social network account). The average of the IT education department was higher than the other departments. The average of English education department was lower than other departments. The teacher candidates who are studying in these departments can be said to be conscious about social networking friends lists and security. In SSNS, there was a significant difference in terms of the total departments. When the averages of the departments were examined, the IT education department had the highest average. IT education department students need to spend much more time with the Internet and social networks, as required by the department courses. Erdemci et al. (2017) found that the students used social networks more than 5 hours on average and 54 of them used 3-5 hours a day. Also, due to the security issues in the course content, it is expected that students of the IT education department should be more careful about using safe social networks compared to other department students. In general, and in some sub-dimensions, it is possible to say that noninformation technology teaching departments exhibit secure behaviors in medium and high 
consciousness, that young people use social networks intensively, that they have been using social networks since their early ages, and that security issues are addressed in IT classes.

When examining the status of licensed anti-virus use of the SSNS behavior of teacher candidates, significant differences have been found in the $3^{\text {rd }}$ factor, social network friend list and security, the $4^{\text {th }}$ factor social network login Information security, the $5^{\text {th }}$ factor secure access to social network account, and the total scale scores. The SSNS behavior of participants using licensed antivirus was higher than those who did not use licensed antivirus software. In the research conducted in Frrat and Bitlis Universities by Yildırım and Varol (2013), many users do not use antivirus software although they think that the security on the social network websites is not satisfactory and sufficient. Today, many universities support free licensed antivirus programs for faculty and students. Students should be made aware of the tens of threats that may come from social networks and be informed about this service of universities. Students who do not know how to use the Antivirus program should also be offered training services.

When examining the lessons of teacher candidates for a safe and conscious social network use of SSNU behavior, significant differences have been found in the $1^{\text {st }}$ factor, Timeline/Wall shares, the $5^{\text {th }}$ factor secure access to social network account, and the total scale scores. On average, it has been seen that participants who have learned to use a safe and conscious social network had higher scores than those who did not receive these lessons. This finding reveals the necessity of providing students with safe and conscious social networking training. In order to raise awareness of online risks in the field, studies emphasizing the importance of education in school (Patchin \& Hinduja, 2010; Tejedor \& Pulido, 2012) should be conducted. Kinay (2012) recommends the preparation of interactive sites and software aimed at increasing the awareness and sensitivity of young people. In their research, Celen et al. (2011) emphasized that it is possible for children and young people to face risks in online environments and that personal protection measures such as websites, secure search methods, and online security resources should be supported to prevent these risks.

As a consequence of the analysis conducted whether the levels of use of the safe social network by teacher candidates vary based on being sufficiently knowledgeable regarding the privacy policy, terms of use, and special conditions of the social networks used, significant differences have been found. Yavanoglu et al. (2012) have highlighted that the privacy policy of the websites, terms of use, and special conditions are required to be read by the individuals prior to sign in and the individuals are required to be aware and conscious of the conditions that the personal data can be shared with the third parties. Ermisoglu (2016) has compared the social network websites in terms of information security. The social networks in this study are defined as communication and sharing environments in which responsibility is assumed when using, requiring a certain user awareness and responsibility. In other words, having sufficient knowledge of the privacy policy and terms of use and special conditions thereof is highly significant in terms of personal security. In the study conducted by Oz (2014) researching the privacy awareness of Facebook users, it is revealed that the higher privacy awareness of social network users results in more discreet user profiles. In other words, the more knowledgeable the users get on the privacy policies of the social networks they behave more carefully in their personal data to be shared with other users in their profiles and in their posts.

Significant differences have been found in the levels of use of the safe social network by teacher candidates according to being sufficiently knowledgeable regarding the law on the protection of personal data. Law on Protection of Personal Data dated 24/3/2016 and numbered 6698 aims to protect the fundamental rights and freedom of individuals in the processing of personal data, particularly the right of privacy and to regulate the obligations of the real and legal entities processing the personal data and the principles and procedures to be abided by them. As it is explicitly stated in Article 17 of the Law, the provisions of Article 135 and 140 of the Turkish Penal Code Nr. 5237 and dated 26/9/2004 shall apply in terms of offenses against personal data. In accordance with these articles, pecuniary penalties, non-judicial penalties, and imprisonment can be applied to the individuals. The details of the Law on Protection of Personal Data are described on the website of the Authority of Protection of Personal Data. The law explicitly clarifies the issue 
of ensuring the security of individuals regarding the access and confidentiality of data thereof and other individuals in data processing environments. It is required to be ensured that this law is explicitly and clearly described and explained in printed and electronic media that are accessible to individuals and that everyone has the awareness and consciousness.

Differences were observed in the teacher candidates' level of security and conscious use of social networks based on the circumstances that they find themselves sufficient and qualified. When the $3^{\text {rd }}$ factor, the $5^{\text {th }}$ factor, and SSNS scale means were examined, it is observed that the mean at the sub factors and total scales of students who find themselves sufficient and qualified on the conscious and safe use of the social network was higher than the ones who did not think of themselves as sufficient.

Significant differences were observed in the total scores of the 2nd factor, the 4 th factor, and SSNS according to the time the teacher candidates spend on the social networks. The teacher candidates spending less than 1 hour on the social networks reveal a more safe use of social network behavior compared to the ones spending 1-3 hours, 4-6 hours, and 7 hours and higher on the social network. This situation can be correlated to the privacy concerns of the teacher candidates. Ku et al. (2013) have stated the higher privacy concern of the individual results in the reduction of time spent on the social network. As most of the participants of this study were females, when the studies revealing the finding that the privacy concerns of females were higher (Garbarino \& Strahilevitz, 2004; Hoy \& Milne, 2010; Youn \& Hall, 2008) are taken into consideration, it can be stated that the ones spending less than 1 hour on the social network tend to use the social networks more conscious and secure.

Significant differences were observed in the total scores of the 1st factor, the 2 nd factor, the 4 th factor, the 5th factor, and SSNS according to the number of social networks the teacher candidates have. The ones with 1-3 social network account(s) had a higher mean than the ones with 4-6 and 7 and higher accounts. It can be stated that people who have fewer social network accounts have safer social network behaviors than those who have more social network accounts. Based on the report acquired by the collaborative study of Hootsuite and We Are Social enterprises, the number of social networks per person was 8.4 in January 2021 (Kemp, 2021a) while this number was 9.4 in Turkey (Kemp, 2021b). Besides, it is highlighted in the lessons that opening different social network accounts for different objectives and purposes would be accurate and appropriate. For instance, people should prefer having Instagram, etc. for photograph sharing, Youtube, etc. for video sharing, Twitter, etc. for short messages and posts, and LinkedIn for sharing and posts related to business life. Occasionally, individuals open accounts with fake identifications apart from their real identities for various reasons whatsoever. Therefore, the number of social network accounts owned by more than half of the teacher candidates was between 4-6. The fact that the conscious and safe use of the social network of the ones with 1-3 social network account(s) can be correlated with the fact that the students have enough time to manage a few social networks.

\section{Recommendations}

The subject of Safe Internet Use taught within the scope of compulsory courses in Faculties of Education is required to be extended in terms of scope. Detailed and practical education and training contents in aspects such as possible threats, netiquettes, security precautions, and measures, legal rights, and obligations, protection of the personal data and privacy, digital footprint, secure password creation, privacy and security settings of social networks are required to be established.

Cyber Security courses are required to be made available for the students who intend to develop themselves in addition to the Information Technologies course. The collaboration among the field experts (such as cyber security experts, psychologists, attorneys), non-governmental organizations (associations/foundations, etc.), and relevant public and official institutions (Scientific and Technological Research Council of Turkey, Information Technologies and Communication Authority, Security Directorates, Judiciaries, etc.) should be established within the scope of these courses. 
Activities and events that aim to raise awareness are required to be organized for teacher candidates on social networks and on the Internet during the period elapsed until graduation. Due diligence should be exercised for these activities and events to be periodical, complementary, and aimed to fulfill the needs. Furthermore, contests among the teacher candidates can be arranged and organized with respect to the story, poster, short film, composition, and security software development related to the subject matter.

In order for the teacher candidates to use social networks predominantly for educational purposes, instructors are also required to be supported for the integration of the social networks into their courses. For the sake of facilitating this integration, in-service pieces of training are required to be provided to the instructors. Furthermore, they are ensured to be knowledgeable on the possible security threats, adverse impacts thereof mean of protection and legal rights and obligations.

Organization directors shall have one of the most substantial roles in the integration of the social networks to education. Managers being knowledgeable and equipped with skills in the use of conscious and secure social networks should encourage instructors accordingly. Besides, the required precautions and measures (security of the corporate network, PC security, etc.) should be taken and corporate policies should be established in this direction to ensure the security of the corporate information security. Everyone who is basically a part of the organization is ensured to be knowledgeable regarding these policies. Corporate social network accounts are required to be established and used actively. Because social networks are a part of the ecosystem in where the digital natives receive education and training and therefore is of substantial importance.

Kevin Mitnick, the world's renowned and infamous hacker of all times has stated that the weakest link in the security chain is the people. From this fact forth, the most substantial step in ensuring the security of the social networks should be education and training. Training of the teacher candidates is of substantial importance in many aspects: ensuring personal e-security, exercising behaviors and attitudes not posing a threat to corporate and national e-security, and being a role model and informative to students, parents, and inner circles. Besides the social network and internet security pieces of training of teacher candidates, the fact that the entire individuals constituting the society are knowledgeable, with the required skills and awareness is an important aspect for the national security. Therefore, activities are required to be organized and held under the leadership of the relevant Ministries and the collaboration of the entire public and private institutions and organizations to raise social awareness.

Acknowledgements. This paper is the extended version of a contribution to the second International Conference of Pedagogical Research (ICOPR) which was held on May 15-16, 2021 with the hostage of Universiti Utara Malaysia.

Author contributions: All authors have sufficiently contributed to the study, and agreed with the results and conclusions.

Funding: No funding source is reported for this study.

Declaration of interest: No conflict of interest is declared by authors.

\section{References}

Akgun, O. E. \& Topal, M. (2015). Information security awareness of the senior teacher students: Sakarya University sample. Sakarya University Journal of Education, 5(2), 98-121.

Akuzum, C. \& Ucar, M. B. (2015). Self-efficacy and concerns of preservice teachers towards social media use as an educational tool. Mevlana International Journal of Moral and Values Education, 2(1), 303-323.

Alpert, J. D. (2020). Continued education for adults with intellectual and developmental disabilities: a phenomenological study of post high school programming [Unpublished Doctoral dissertation]. Faculty of The University of Texas at Dallas. 
Ariturk, M. (2015). Comparison of information awareness and information security. XVII. Academic Informatics Conference, Anatolian University, Eskişehir, Turkey.

Buyukozturk, Ş., Çakmak-Kılıç, E., Akgun, O. E., Karadeniz, Ş., \& Demirel, F. (2011). Bilimsel araştırma yöntemleri [Scientific Research Methods]. Ankara.

Cabral, A. R. (2022). Ransomware attacks surge by 151\% in first half of 2021 as global digital economy thrives. Retrieved from https:/ / english.sawtbeirut.com/business/ransomware-attacks-surge-by-151-in-first-half-of-2021-asglobal-digital-economy-thrives/

Cakir, M. (2020). A qualitative research on experiences of adult individuals using social media: the case of Karaman. Karamanoğlu Mehmetbey University Journal of the Faculty of Letters, 3(1), 91-105.

Cam, E. (2012). Pre-service teachers' use of Facebook for educational and general purposes and their dependencies on Facebook. (SAU: faculty of education example). [Unpublished Master Thesis]. Sakarya University Institute of Educational Sciences.

Carpenter, J. P. \& Krutka, D. G. (2015). Social media in teacher education. In J. P. carpenter \& D. G. Krutka (Eds.), Handbook of research on teacher education in digital age (pp. 28-54). IGI Global.

Carter, L. A. (2020). New teacher induction in the age of social media: a phenomenological study of teachers in their second and third year in the classroom. doctoral dissertations and projects. Retrieved from https:/ / digitalcommons.liberty.edu/doctoral/2363.

Celen, F. K., Celik, A., \& Seferoglu, S. S. (2011). Children's internet use and online risks awaiting them. Academic Informatics Conference, 2-4 February 2011, Malatya, Turkey.

Celik, İ., Yurt, E., \& Sahin, İ. (2015). A model for understanding Educational Facebook use. Eurasia Journal of Mathematics, Science \& Technology Education, 11(4), 899-907. https:/ / doi.org/10.12973/ eurasia.2015.1447a

Ceyhan E. B., Demiryurek E., \& Kandemir B. (2015). Current security risks and prevention methods in social networks. International Journal of Information Security Engineering, 1(1), 1-10.

Cihan, M. \& Yıldız, S. (2021). Sosyal medya aracıllğı ile işlenen suçlar: facebook, twitter ve instagram örnekleri [Types of crimes that are committed through social media: Samples of facebook, twitter and instagram]. Kirikkale University Journal of Social Sciences, 11(1), 135-150.

Cohen, L., Manion, L., \& Morrison K. (2000). Research methods in education. Routledge Falmer.

Cybint. (2020). 15 Alarming cyber security facts and stats. Retrieved from https:/ / www.cybintsolutions.com/cyber-security-facts-stats/

Damico, N. \& Krutka, D. G. (2018). Social media diaries and fasts: Educating for digital mindfulness with pre-service teachers. Teaching and Teacher Education, 73, 109-119. https:// doi.org/10.1016/j.tate.2018.03.009.

Erdemci, H., Elcicek, M., \& Karal, H. (2017). A study on information sharing behavior of information technology teacher candidates in social networks. International Symposium of Turkish Computer and Mathematics Education-3, 17-19 May 2017, Afyon, Turkey.

Erdogmus, A. (2017). Analyzing the effects of information security achievements of university students on awareness: Afyon Kocatepe University sample [Unpublished Master's Thesis]. Afyon Kocatepe University, Turkey.

Ermisoglu, D. (2016). Comparison of social security sites in terms of information security. Academia Journal of Social Sciences, 2(1), 40-47.

Garbarino, E. \& Strahilevitz, M. (2004). Gender differences in the perceived risk of buying online and the effects of receiving a site recommendation. Journal of Business Research, 57, 768-775. https:/ / doi.org/10.1016/S0148-2963(02)00363-6

Gasaymeh Al-Mothana, M. (2017). University students use of whatsapp and their perceptions regarding its possible integration into their education. Global Journal of Computer Science and Technology, 17(1), 1-9.

Genden, S. N. (2015). Worker use of social media for informal learning in a corporate environment [Unpublished doctoral dissertation]. Wayne State University Dissertations, Paper 1130.

Hoy, M.G. \& Milne, G. (2010). Gender differences in privacy-related measures for young adult Facebook users. Journal of Interactive Advertising, 10, 28-45. https:/ / doi.org/10.1080/15252019.2010.10722168

Hutchison, A. \& Wang, W. (2012. Blogging within a social networking site as a form of literature response in a teacher education course. Educational Media International, 49(4), 263-275. https:/ / doi.org/10.1080/09523987.2012.741197

Kemp, S. (2021a). Digital 2021 global overview report. Retrieved from https://wearesocial.com/digital-2021.

Kemp, S. (2021b). Digital 2021 Turkey. Retrieved from https://dateportal.com/reports/digital-2021turkey?rq=turkey

Kemp, S. (2022). Digital 2022: Global overview report. Retrieved from https:/ / datareportal.com/reports/digital-2022-global-overview-report 
Kinay, H. (2012). The relationship between high school students' cyberbullying sensitivity with risky behavior, protective behavior, exposure to crime, and perception of danger and to examine various variables [Unpublished Master's thesis]. Sakarya University, Institute of Educational Sciences, Turkey.

Ku, Y.C., Chen, R., \& Zhang, H. (2013). Why do users continue using social networking sites? an exploratory study of members in the United States and Taiwan. Information $\mathcal{E}$ Management, 50, 571-581. https:/ / doi.org/10.1016/j.im.2013.07.011

Lazic, M. (2021). 39 worrying cyber crime statistics. Retrieved from https://legaljobs.io/blog/cyber-crimestatistics/

Lee, B. \& Sin Sing, A. (2013). Social media as an informal learning platform: Case study on adult learning at SIM University, Singapore [Paper presentation]. 3rd World Conference on Learning, Teaching and Educational Leadership (WCLTA-2012).

Mozhaevaa, G., Feshchenkoa, A., \& Kulikova, I. (2014). E-learning in the evaluation of students and teachers: LMS or social networks? Procedia - Social and Behavioral Sciences, 152, 127 - 130. https:// doi.org/10.1016/j.sbspro.2014.09.168

Nitza, D. \& Roman, Y. (2016). WhatsApp messaging: Achievements and success in academia. International Journal of Higher Education, 5(4), 255-261.

Nochumson, T. C. (2020). Elementary schoolteachers' use of Twitter: exploring the implications of learning through online social media. Professional Development in Education, 46(2), 306-323. https:/ / doi.org/10.1080/19415257.2019.1585382

Ohlhorst, F. (2021). Social media risks increasing in 2021. Retrieved from https:/ / www.cybersecurityinformer.com/media/ ?open-article-id=15566560\&article-title=social-mediarisks-increasing-in-2021\&blog-domain=securityboulevard.com\&blog-title=security-boulevard

Oz, M. (2014). Changes in Use and Perception of Privacy: Exploring Facebook users' privacy concerns and awareness of privacy implications. Journal of Yasar University, 35(9), 6245-6254. https://doi.org/10.19168/jyu.96978

Patchin, J. W. \& Hinduja, S. (2010). Changes in Adolescent Online Social Networking Behaviors from 2006 to 2009. Computer Human Behavior, 26(6), 1818-1821. https:// doi.org/10.1016/j.chb.2010.07.009

Probasco, J. (2022). Huge surge in 2021 social media scams, says FTC. Retrieved from https:/ / www.investopedia.com/social-media-scams-surging-5217274

Rashid, A. B., Yahaya, M. F., Rahman, M. F. A., \& Yunus, K. (2016). Teachers' informal learning via social networking technology. IJET, 11(10), 76-79.

Sebetci, O., Topal, A., Hanayli, M. C., \& Donuk, G. G. (2018). Perceptions of university students on whatsapp in educational settings. Route Educational and Social Science Journal, 5(6), 63-76.

Sharma, A. (2021). Top 10 cyber crime trends to watch for in 2022. Retrieved from https:/ / www.thenationalnews.com/business/technology/2021/12/29/top-10-cyber-crime-trends-towatch-out-for-in-2022/

Shinde, S. (2022). Social media crime recorded 100\% rise in 2021 in Pune. Retrieved from https:/ / www.hindustantimes.com/cities/ pune-news/social-media-crime-recorded-100-rise-in-2021-inpune-101642440822471.html

Stouffer, C. (2021). 115 cybersecurity statistics and trends you need to know in 2021. Retrieved from https:/ / us.norton.com/internetsecurity-emerging-threats-cyberthreat-trends-cybersecurity-threatreview.html

Sturkenboom, M. E. A. (2020). Digitalisation for all of us?! - Uncovering the social imaginary of the Dutch government regarding adult digital literacy [Unpublished Master's thesis]. Utrecht University, Faculty of Humanities Theses, Holland.

Tejedor, S. \& Pulido, C. (2012). Challenges and risks of internet use by children: how to empower minors. Comunicar, 39, 65-72.

The Ministry of National Education. [MoNE]. (2018). 2023 eğitim vizyonu [Education of Vision]. Retrieved from http:/ / 2023vizyonu.meb.gov.tr/doc/2023_EGITIM_VIZYONU.pdf

The Ministry of National Education. [MoNE]. (2017). Öğretmenlik mesleği genel yeterlikleri [General competencies of teaching profession]. Retrieved from http://oygm.meb.gov.tr/meb_iys_dosyalar/2017_12/11115355_YYRETMENLYK_MESLEYY_GENEL_Y ETERLYKLERY.pdf.

Topal, M. \& Akgun, O. E. (2015). Examination of self-efficacy perceptions of pre-service teachers studying at the faculty of education for educational purposes: Sakarya University example. Kastamonu Journal of Education, 23(1), 343-364. 
Tosun, N. \& Gecer, A. (2022). A safe social networking scale: the study of development, validity and reliability. Athens Journal of Mass Media and Communications, 8(3), 179-200.

Tosun, N. (2018). Social networks as a learning and teaching environment and security in social networks. Journal of Education and Training Studies, 6(11), 194-208.

Trust, T. \& Prestridge, S. (2021. The interplay of five elements of influence on educators' PLN actions. Teaching and Teacher Education, 97, 1-12. https:// doi.org/10.1016/j.tate.2020.103195

Trytten, B. K. (2018). Digital technology and teacher preparation: the instructional role of social media among preservice teachers [Unpublished Doctoral dissertation]. Graduate Faculty of the University of Kansas.

Yavanoglu, U., Sagıroglu, Ş., \& Colak, İ. (2012). Information security threats and taking privacy precausions in social networks. Journal of Polytechnic, 15(1), 15-27.

Yaylak, E. \& İnan, S. (2018). Investigation of social studies teachers' opinions on the use of social media in education. TUBAD, 3(1), 1-32.

Yildirim, N. \& Varol, A. (2013). Security in social networks: A field study in Bitlis Eren and Firat Universities. Journal of Turkey Informatics Foundation of Computer Science and Engineering, 7(7), 285-292.

Youn, S. \& Hall, K. (2008). Gender and online privacy among teens: risk perception, privacy concerns, and protection behaviors. Cyberpsychology Behaviour, 11, 763-765. https://doi.org/10.1089/cpb.2007.0240 